\title{
ASSESSMENT OF PRODUCTIVE AND ENVIRONMENTAL EFFICIENCY OF SLOW-RELEASE FERTILIZERS IN INTEGRATED PRODUCTION OF NAPA CABBAGE DEPENDING ON APPLICATION METHOD
}

\author{
Marcin NIEMIEC, Department of Agricultural and Environmental Chemistry, Faculty of Agriculture and Economics, \\ University of Agriculture in Krakow, Al. Mickiewicza 21, 31-120 Krakow, Poland, marcin1niemiec@gmail.com \\ (corresponding author)
}

Monika TABAK, Department of Agricultural and Environmental Chemistry, Faculty of Agriculture and Economics, University of Agriculture in Krakow, Al. Mickiewicza 21, 31-120 Krakow, Poland, monika.tabak@ur.krakow.pl

Lukasz PALUCH, Institute of Economic and Social Sciences, Department of Economy and Economic Policy, Faculty of Agriculture and Economics, University of Agriculture in Krakow, Al. Mickiewicza 21, 31-120 Krakow, Poland; lukasz.paluch@ur.krakow.pl

Monika KOMOROWSKA, Department of Vegetable and Medicinal Plants, Faculty of Biotechnology and Horticulture, University of Agriculture in Krakow, Al. 29 Listopada 54, 31-425 Krakow, Poland, komorowska.monika@interia.pl

The study aimed to assess the suitability of slow-release fertilizers in cultivation of napa cabbage in the integrated production system. The objective was realized on the basis of a strict field experiment set up on soil with granulometric composition of light loam. The dose of fertilizer was the first experimental factor, and the fertilizer application was the second factor. The slow-acting fertilizer was applied under each plant during planting of seedlings and in the second variant. The fertilizer was applied in the row, about $5 \mathrm{~cm}$ under the seedling root level. On the basis of the results obtained in the experiments, the indices showing nitrogen fertilization efficiency were calculated

Fertilization significantly modified the quantity of obtained yield. In the control, without mineral fertilization, the crop yield was 23.32 $\mathrm{Mg} \mathrm{ha}^{-1}$. The largest yield was $52.27 \mathrm{Mg} \mathrm{ha}^{-1}$. Larger yields and more advantageous productive and environmental efficiency were obtained in objects with row application of fertilizer. The most advantageous agronomic efficiency and nitrogen recovery efficiency were obtained in the combination of $400 \mathrm{~kg} \mathrm{ha}^{-1}$ of slow-acting fertilizer with traditional supplementary PK fertilizers in the case of point application of fertilizers. In the case of row fertilizer application, it is possible to use $50 \%$ more of the fertilizer dose without compromising the quality of the crop. Higher doses of free-acting fertilizers increased the standard deviation of the mass of cabbage, which is not desirable for production. The results show that under conditions of low mineral content in the soil, the slow-acting fertilizers can be used at a low level.

Keywords: napa cabbage, integrated production, slow-acting fertilizer, fertilization efficiency

\section{INTRODUCTION}

Agriculture is perceived as one of the most important factors that shape the environment. Attention is most often drawn to the problem of emission of greenhouse gases, biogens and organic compounds which are active substances of pesticides. Intensification of crop production and the necessity to increase the amount of fertilizers and pesticides used that is associated therewith can have a negative effect on the quality of plant products intended for food and feed. The desire to produce agricultural products characterized by a low content of harmful substances using environmentally friendly technologies results from the shaping of consumer preferences, particularly in developed countries. Quality of food products, understood as the level of consumer satisfaction, is associated not only with product safety and sensory parameters, but also with production technology based on rationalization of the use of natural resources and energy (Alluvione et al., 2011). Social practices and their conformity local law and international workers' rights conventions are very important issues connected with organization of production in agriculture. The needs of the market of food products were met by creating primary production quality systems which in a comprehensive way present the issues of the environment, product safety, social and economic aspects. The most important systems include Integrated Production, GLOBAL G.A.P., SAI. The issue of plant nutrition optimization is a very important part of all the above-mentioned quality systems in primary production. Crop fertilization is the most important agrotechnical measure that determines the yield amount and quality. Moreover, elements not used by plants are dispersed into the environment, leading to

Copyright (C) 2017 The Authors. Published by Aleksandras Stulginskis University. This is an open-access article distributed under the terms of the Creative Commons Attribution License (CC-BY 4.0), which permits unrestricted use, distribution, and reproduction in any medium, provided the original author and source are credited. 
intensification of eutrophication processes and the greenhouse effect. Optimization of fertilization is therefore a strategic area for development of agriculture and shaping its image in the present-day world (Mzoughi, 2011). The efficiency of crop production under field conditions is conditioned by numerous factors connected with the properties of soil ecosystem's biotope and biocenosis, and with climatic conditions and the broadly understood agricultural technology. The effect of above-mentioned procedures is production of high quality food in terms of chemical composition and technological parameters. To obtain satisfactory results, both abiotic and biotic parameters of the agroecosystem and also production capacities of crops should be taken into account (Helandar and Delin, 2004).

Therefore, implementation of effective fertilization methods is very difficult and often does not bring desired production effects. It is one of the main causes of the small interest of producers (Gaetano et al., 2016). Sustainable agriculture is based on the use of cultivation techniques that make it possible to obtain high yields of good quality with rational use of soil resources, energy and chemical means of production. The idea of sustainable agriculture is being implemented within various quality systems such ecological farming, integrated farming. The aim of implementing quality systems in primary agricultural production is to produce high quality yields, while simultaneously respecting the aspects of environmental protection. Intensive development of quality systems for agricultural production that took place at the turn of the 20th and 21st centuries was the answer to problems connected with global degradation of the environment. It was also connected with increasingly common cases of detecting substantial amounts of harmful compounds in food, which was a consequence of improper use of pesticides. Measures that were taken in order to reduce pesticide use made it obligatory for agricultural producers to use integrated methods of protection (Mzoughi, 2011). Inspections connected with the use of pesticides and campaigns that promote products with the quality systems logo among consumers increase the awareness among producers and consumers.

The aim of the conducted research was to determine the usefulness of using slow-acting fertilizers in Chinese cabbage fertilization using two fertilization methods. The efficiency of nitrogen fertilization was evaluated based on indices of fertilization efficiency such as: Agronomic efficiency, productivity rate and removal efficiency (IFA, 2007). Indices that reflect fertilization efficiency provide a lot of information about environmental and production-related aspects of nitrogen fertilization.

To achieve the pursued objective, two field experiments that differed in the method of application of slow-acting fertilizer were conducted. The slow-acting fertilizer was applied pointwise and in rows, approximately $5 \mathrm{~cm}$ below plant roots. Using slow-acting fertilizers directly under the root limited plant growth and increased differences in the size of individual plants, which is unfavorable from the point of view of the commercial quality of the product (Niemiec, 2014; Niemiec et al., 2015a). The experiment was set up on soil with the granulometric composition of sandy loam. Broad bean grown in the same year was the forecrop for the studied plants. The test plant was Chinese cabbage (Brassica rapa L.), 'Parkin F1' cv. The experiment was set up on 11 Aug 2016. The plants were harvested on 19 Oct 2016. The plants were cultivated at $50 \mathrm{~cm} \times 30 \mathrm{~cm}$ spacing, from seedlings prepared in multi-cell trays (VEFI system). Varied fertilization and the manner of fertilizer application were the factors of the experiment. Cultivation and protection of the plants were carried out based on the methodology of integrated production of Chinese cabbage (Methodology, 2013). The following were determined in the soil: reaction, granulometric composition, organic matter content, mineral nitrogen content, Kjeldahl nitrogen content and the content of available forms of $\mathrm{P}, \mathrm{K}, \mathrm{Mg}$ and $\mathrm{Ca}$ (Table 1.).

Table 1. Selected properties of soil used for experiments $\mathrm{mg} \cdot \mathrm{kg}^{-1}$

\begin{tabular}{cccccccccc}
\multirow{2}{*}{$\mathrm{pH}$ in $\mathrm{H}_{2} \mathrm{O}$} & \multirow{2}{*}{$\mathrm{pH}$ in $\mathrm{KCl}$} & \multicolumn{3}{c}{$(\%)$} & \multicolumn{5}{c}{$\mathrm{mg} \cdot \mathrm{kg}^{-1}$} \\
\cline { 3 - 9 } & & Kiejdahl N & Organic C & Mineral N & $\mathrm{P}$ & $\mathrm{K}$ & $\mathrm{Mg}$ & $\mathrm{Ca}$ \\
\hline 6.63 & 6.01 & 0.182 & 1.88 & 102 & 116.2 & 262.3 & 88.4 & 856.6 \\
\hline
\end{tabular}

For each fertilization variant, documentation of production and technological processes was kept and it was compliant with guidelines included in the Regulation (Regulation, 2013). The plants were irrigated up to the optimum moisture content in order to eliminate the impact of water stress on the result of the experiments. Prior to setting up the experiment, analyses of physicochemical and chemical properties of the soil on which the experiment was set up had been conducted. The following were determined in the soil: reaction, granulometric composition, organic matter content, mineral nitrogen content, Kjeldahl nitrogen content and the content of available forms of $\mathrm{P}, \mathrm{K}, \mathrm{Mg}, \mathrm{Ca}$ and the other macroelements and microelements.

A slow-acting multicomponent fertilizer with $\mathrm{NPK}(\%)$ 19-05-20+4CaO+4MgO+19,5 $\mathrm{SO}_{3}$ and ammonium nitrate was used in the experiment. Moreover, triple superphosphate and $60 \%$ potassium salt were used. The experience comprised three levels of fertilization with the use of slow-acting fertilizers, the control without fertilization and the control fertilized with traditional fertilizers in the amount corresponding to plant demand for nutrients, assuming the yield would be at the level of $60 \mathrm{Mg} \cdot \mathrm{ha}^{-1}$. The slow-acting fertilizer was applied pointwise under each plant, and in rows approximately $5 \mathrm{~cm}$ below the root level. Phosphatic and potassium fertilizers were applied in their entirety prior to sowing, whereas ammonium nitrate was divided into two doses: $60 \%$ of the dose was applied prior to planting and $40 \%$ after planting. The date for topdressing was selected based on the observations of meteorological conditions and monitoring of the condition of the plants. The scheme of the experiment is presented in Table 2. The experiment was carried out in four replications using the randomized blocks method. The obtained results of mean element contents were compared using the student's t-test, at the significance level of $\mathrm{p}=0.05$. 
Table 2. Experimental design

\begin{tabular}{|c|c|c|c|c|c|c|c|}
\hline Treatment number & $\begin{array}{l}\text { slow-acting } \\
\text { fertilizer }\end{array}$ & $\begin{array}{c}\text { ammonium } \\
\text { nitrate } \\
\text { kg fertil }\end{array}$ & $\begin{array}{c}\text { triple } \\
\text { superphosphate } \\
\cdot \text { ha }^{-1}\end{array}$ & $\begin{array}{l}\text { potassium } \\
\text { salt }\end{array}$ & \multicolumn{3}{|c|}{$\mathrm{kg}$ component $\cdot \mathrm{ha}^{-1}$} \\
\hline control & - & - & - & - & - & - & - \\
\hline 1 & - & 400 & 68 & 200 & 126 & 30 & 120 \\
\hline \multicolumn{8}{|c|}{ pointwise application } \\
\hline 2 & 200 & - & 45 & 130 & 72 & 30 & 120 \\
\hline 3 & 400 & - & 22.5 & 65 & 90 & 30 & 120 \\
\hline 4 & 600 & - & - & - & 108 & 30 & 120 \\
\hline \multicolumn{8}{|c|}{ rows application } \\
\hline 5 & 200 & - & 45 & 130 & 144 & 30 & 120 \\
\hline 6 & 400 & - & 22.5 & 65 & 50 & 30 & 120 \\
\hline 7 & 600 & - & - & - & 100 & 30 & 120 \\
\hline
\end{tabular}

Increasing the efficiency of fertilization, especially with nitrogen and phosphorus, is one of priority goals of agricultural sciences and production practice. Optimization is connected with using slow-acting fertilizers or fertilizers containing nanoparticles (Liu and Lal, 2015).

Table 3. Results of conducted experiment

\begin{tabular}{|c|c|c|c|c|c|c|c|}
\hline $\begin{array}{l}\text { Variant of } \\
\text { experiment }\end{array}$ & $\begin{array}{c}\text { Mean } \\
\text { marketable } \\
\text { yield }\end{array}$ & Range & $\begin{array}{c}\text { Mean } \\
\text { cabbage } \\
\text { head weight }\end{array}$ & Range & $\begin{array}{l}\text { Partial factor } \\
\text { productivity }\end{array}$ & $\begin{array}{l}\text { Agronomic } \\
\text { efficiency }\end{array}$ & $\begin{array}{l}\text { Removal } \\
\text { efficiency }\end{array}$ \\
\hline Unit & $\mathrm{Mg} \cdot \mathrm{ha}^{-1}$ & $\mathrm{Mg} \cdot \mathrm{ha}^{-1}$ & $g \cdot$ unit $^{-1}$ & $\mathrm{~g} \cdot$ unit $^{-1}$ & ${ }_{1}^{\mathrm{kg} \mathrm{f}}$ f.m. $\cdot \mathrm{kg} \mathrm{N}^{-}$ & $\begin{array}{l}\mathrm{kg} \text { d.m. } \cdot \mathrm{kg} \\
\text { fertilizer }^{1}\end{array}$ & $\begin{array}{l}\mathrm{kgN} \mathrm{kg} \cdot \mathrm{N} \\
\text { applied }^{-1}\end{array}$ \\
\hline Control & $23.32 \mathrm{a}$ & $21.22-24.99$ & $424 a$ & $388-556$ & - & - & - \\
\hline 1 & $48.38 \mathrm{c}$ & $44.62-50.56$ & $879 \mathrm{c}$ & $688-921$ & $310.1 \mathrm{a}$ & $7.062 b$ & $0.619 b$ \\
\hline 2 & $35.88 \mathrm{~b}$ & $32.56-36.82$ & $652 b$ & $439-691$ & $629.5 c$ & $10.00 \mathrm{c}$ & $1.024 \mathrm{~d}$ \\
\hline 3 & $44.29 b c$ & $38.56-49.88$ & $805 b c$ & $566-1034$ & $466.2 b$ & $9.70 \mathrm{c}$ & $0.758 \mathrm{c}$ \\
\hline 4 & $35.88 \mathrm{abc}$ & $27.89-47.56$ & 652abc & $422-1588$ & $269.8 \mathrm{a}$ & $4.161 \mathrm{a}$ & $0.501 \mathrm{a}$ \\
\hline 5 & $35.96 b$ & $33.48-36.82$ & $653 \mathrm{bc}$ & $499-811$ & $630.9 \mathrm{c}$ & $9.950 \mathrm{c}$ & $0.913 d$ \\
\hline 6 & $42.96 b c$ & $38.29-44.67$ & $781 \mathrm{bc}$ & $612-988$ & $452.2 \mathrm{~b}$ & $8.867 \mathrm{bc}$ & $0.715 b$ \\
\hline 7 & $52.27 \mathrm{bc}$ & $41.66-56.88$ & $950 \mathrm{c}$ & $662-1358$ & $393.01 \mathrm{ab}$ & $8.593 b c$ & $0.604 \mathrm{bc}$ \\
\hline
\end{tabular}

Different letters at mean values indicate the statistically significant differences between the objects at $\mathrm{p}=0.05$.

The amount of yield is the most important parameter in the assessment of economic efficiency of agricultural production from the producer's point of view. In our research, the yield obtained in the control treatment was at the level of 23.32 $\mathrm{Mg} \cdot \mathrm{ha}^{-1}$ (Table. 3). For fertilization resulting from fertilizer needs of the cultivated plants, a commercial yield of $48.38 \mathrm{Mg} \cdot \mathrm{ha}^{-1}$ was obtained. Fertilization in the amount of $200 \mathrm{~kg}$ slow-acting fertilizer caused an increase in the quantity of commercial yield by approximately $50 \%$. The highest yield $\left(52.27 \mathrm{Mg} \cdot \mathrm{ha}^{-1}\right)$ was obtained in fertilization variant 7 with the addition of $600 \mathrm{~kg}$ slow-acting fertilizer applied in rows (Table. 3). In the case of point application of fertilizers, the highest yield was obtained with a $400 \mathrm{~kg}$ addition of a slow-acting fertilizer. Increasing the amount of fertilizer up to $600 \mathrm{~kg}$ caused a decrease in plant yielding. Niemiec (2014) also observed a decrease in Chinese cabbage yielding after application of $600 \mathrm{~kg}$ slow-acting fertilizer directly under root. Results obtained in this research, in confrontation with literature data, can point to no effect of slow-acting fertilizer application depth. However, research conducted by Niemiec (2014) was conducted on soil with a significantly higher abundance of nutrients and a higher amount of clay particles compared to this research. It is possible that the yield inhibition effect was linked to worse growth conditions caused by the increase in salinity in points. The assessment of plant yielding should always be investigated with respect to technological quality, which, among other things, consists in repeatability of product quality. Diversity in cabbage weight is not beneficial from the point of view of introducing the product to the market. Results of the conducted experiment indicate that the highest product repeatability was obtained for fertilization with traditional fertilizers. Variability within this treatment was approximately $20 \%$. Fertilization with the use of slow-acting fertilizers caused an increase in diversification in cabbage head weight. At their highest dose, variability was at the level of $48.7 \%$ for row application and $82.0 \%$ for point application of fertilizers. From the point of view of the amount of yield and product repeatability, the best results were obtained at traditional fertilization. From the point of view of present-day quality standards in primary production, the agricultural system should be assessed using not only production indicators but also environmental indicators (Verzeaux et al., 2017). The manner of fertilizer application is of great importance for reaching set production and environmental goals which are always connected with an increase in fertilization efficiency (Mucheru-Muna et al., 2010; Niemiec et al., 2015a; Nkebiwe et al., 2016). Productivity rate informs how much has plant yield increased after application of $1 \mathrm{~kg}$ nitrogen in the form of fertilizer. In our study it ranged from 269.8 to 630.9. The lowest value of this parameter was found in treatments with the highest dose of a slowacting fertilizer applied in points. On the other hand, the highest productivity rate was observed at application of slow-acting fertilizers in the amount of $200 \mathrm{~kg}$ (Table. 3). Niemiec (2014) found values of production efficiency coefficient of Chinese cabbage grown in soil with a high nitrogen content ranging from 650 to over 1800 . A high productivity rate is characteristic for agroecosystems with a low level of fertilization. Its high value is not necessarily indicative of high production and environmental efficiency of the agricultural system (Dua et al., 2011). 
Agronomic efficiency index is the most important indicator that reflects the efficiency of agricultural systems. The value of agronomic efficiency index for cereal production in developing countries ranges from 10 to $30 \mathrm{~kg}$ of a product . $\mathrm{kg}^{-1}$ nitrogen fertilization (Dobermann, 2007). The value of agronomic efficiency index in individual variants of the experiment ranged between 6.16 and $35.92 \mathrm{~kg} \cdot \mathrm{kg}^{-1}$ expressed as Chinese cabbage dry matter yield, whereas Niemiec et al. (2015a) reported the value of this parameter in conventional cultivation of celery to be approximately $20 \mathrm{~kg} \cdot \mathrm{kg}^{-1}$. The manner of application of nitrogen fertilizers is one of the most effective methods of improving the efficiency of fertilizer nitrogen utilization. Ma et al. (2015) stated that fertilization optimization with respect to the choice of chemical form of nitrogen and the manner of fertilizer application allowed to significantly increase the agronomic efficiency index in maize cultivation, reaching the value of $15 \mathrm{~kg}$ increase in grain weight after application of $1 \mathrm{~kg}$ fertilizer nitrogen. In our study, the value of this parameter ranged between 4.161 and $10 \mathrm{~kg} \cdot \mathrm{kg}^{-1}$ (Table. 3). There were slight differences in the value of this parameter between individual treatments. The highest values of this parameter were observed in the case of application of a slow-acting fertilizer in a dose of $400 \mathrm{~kg} \cdot \mathrm{ha}^{-1}$, and the lowest ones were observed at application of 600 $\mathrm{kg} \mathrm{ha}^{-1}$ slow-acting fertilizer, which was caused by plant growth disturbance.

Removal efficiency is the most important indicator based on which one can assess agricultural systems in terms of the impact on the natural environment. This is because it indicates what part of nitrogen applied in the form of mineral fertilization is removed from the ecosystem with the yield. Due to the low capacity of the soil sorption complex to bind this element, its considerable part that has not been taken up with the yield is dispersed in the environment, leading to intensification of eutrophication processes. Very high values of this parameter are indicative of a deficit level of nitrogen fertilization and proper utilization of nitrogen from soil reserves. On the other hand, its low values suggest occurrence of factors that impair normal functioning of the agroecosystem, such as nutrient deficiency, unfavorable weather conditions or excessive occurrence of pests. With proper resource management, the value of this parameter should fluctuate between 55 and $65 \mathrm{~kg} \cdot \mathrm{ha}^{-1}$ (IFA, 2007). The most frequently observed values of this parameter range from 30 to $90 \mathrm{~kg} \cdot \mathrm{ha}^{-1}$. In the conducted experiment, values of the removal efficiency index varied within the range from 0.501 to $1.24 \mathrm{~kg} \cdot \mathrm{kg}^{-1}$ depending on fertilization variant. The lowest value of this parameter was found in the treatment fertilized with slow-acting fertilizers at points at a dose of $600 \mathrm{~kg} \cdot \mathrm{ha}^{-1}$ and in the conventionally fertilized treatment (Table. 3). The highest values of the removal efficiency index were found in the treatments with the lowest dose of slow-acting fertilizers. The most beneficial removal efficiency index, according to literature data, was obtained in the treatment with a $400 \mathrm{~kg}$ dose of slow-acting fertilizers and a full dose of phosphorus and potassium (IFA 2007). The determined values of the removal coefficient are high in each variant of the experiment. Niemiec (2014) obtained significantly higher values in his experiments with Chinese cabbage crops. Wang et al. (2017) obtained significantly lower values of this parameter in cultivation of agricultural crops. The soil that was used in this experiment was characterized by a high content of mineral nitrogen that remained after forecrop grown in the same year. In such conditions values of the removal efficiency index can reach more than 1 and it does not indicate improper fertilization.

One of the strategic goals of the present day agriculture, common for all quality systems in primary production, is to increase the efficiency of fertilization to reduce production costs and reduce the negative impact of agriculture on the natural environment. The most important problem connected with implementation of precise fertilization systems is that producers have too little knowledge on fertilizer application technologies (Mucheru-Muna, 2010). Efficiency of element utilization from mineral fertilization depends on a lot of factors connected with habitat and climate. Therefore, all fertilizers introduced to the market must be fitted with technology allowing tem to be used in different habitat conditions (Ding et al., 2016). Results of the conducted experiment indicate a substantial potential for using slow-acting fertilizers. Application of a slow-acting fertilizer caused an increase in the value of the productivity coefficient by approximately 50\%, obtaining a yield comparable to that for conventional fertilization at a level compliant with the integrated production principles. The high difference in mass between individual plants is the factor that may limit the use of fertilization technology that utilizes slowacting fertilizers. Niemiec et al. (2015b) stated that the best production and environmental effects can be obtained by fertilizing with conventional fertilizers in conjunction with slow-acting fertilizers applied under root

\section{CONCLUSIONS}

1. Application of slow-acting fertilizers using the row method yields better production results compared to point application of fertilizer under the root level.

2. The most favorable productivity rate and agronomic efficiency index were reached after application of $400 \mathrm{~kg}$ of a slow-acting fertilizer and full fertilization with phosphorus and potassium.

3. In the treatments fertilized with slow-acting fertilizers under root, using both the row method and the point method, the obtained yield was of worse commercial quality compared to the treatment fertilized conventionally (which resulted in more varied weight of the heads).

4. Using a fertilization technology based on the share of controlled release fertilizers may simplify rational management of nutrients in sustainable agriculture.

\section{REFERENCES}

1. Alluvione F., Moretti B., Sacco D., Grignani C. 2011. EUE (energy use efficiency) of cropping systems for a sustainable agriculture. Energy, Vol. 36, pp. 4468-4481. http://dx.doi.org10.1016/j.energy.2011.03.075 
2. Ding H., Zhang Y.S., Li W.H., Zheng X.Z., Wang M.K., Tang L.N., Chen D. L. 2017. Nutrients Release from a Novel Gel-Based Slow/Controlled Release Fertilizer. Applied and Environmental Soil Science, Vol. 2016, Vol. 13, pp. 1-13 http://dx.doi.org/10.1155/2016/2013463

3. Dobermann A. 2007. Nutrient use efficiency, measurement and management. IFA International Workshop on Fertilizer Best Management Practices, pp. 7-9, March 2007, Brussels, Belgium, International Fertilizer Industry Association.

4. Dua V.K., Govindakrishnan P.M., Lal S.S., Khurana S.M.P. 2007. Partial Factor Productivity of Nitrogen in Potato. Better Crops, Vol. 91, Iss. 4, pp. 26-27.

5. Gaetano M., Polinori P., Tei F., Benincasa P., Turchetti L. 2016. An Economic Analysis of the Efficiency and Sustainability of Fertilization Programs at Level of Operational Systems of Soft Wheat in Umbria. Agriculture and Agricultural Science Procedia, Vol. 8, pp. 298-306. https://doi.org/10.1016/S1161-0301(03)00089-3

6. Helander C.A., Delin K. 2004. Evaluation of farming systems according to valuation indices developed within a European network on integrated and ecological arable farming systems. European. Journal of Agronomy, Vol. 21, Iss. 1, pp. 53-67. https://doi.org/10.1016/S1161-0301(03)00089-3

7. IFA. 2007. Sustainable management of the nitrogen cycle in agriculture and mitigation of reactive nitrogen side effects. International Fertilizer Industry Association, Paris, 53 p.

8. Liu R., Lal R. 2015. Potentials of engineered nanoparticles as fertilizers for increasing agronomic productions. Science of The Total Environment, Vol. 514, Iss. 1, pp. 131-139. https://doi.org/10.1016/j.scitotenv.2015.01.104

9. Ma Q., Wang X., Li H., Li H., Zhang F., Rengel Z., Shen J. 2015. Comparing localized application of different N fertilizer species on maize grain yield and agronomic N-use efficiency on a calcareous soil. Comparing localized application of different $\mathrm{N}$ fertilizer species on maize grain yield and agronomic N-use efficiency on a calcareous soil. Plant Science, Vol. 264, pp. 48--56. https://doi.org/10.1016/i.fcr.2015.05.011

10. Methodology of Integrated Production of Chinese Cabbages, second edition revised 2013. Approved on the basis of art. 5 section 3 point 2 of the Act of 18 December 2003 on Plant Protection. Journal of Laws of 2008, No. 133, item 849 as amended, by the Main Inspector of Plant Health and Seed Inspection,

11. Mucheru-Muna M. ,Pypers P., Mugendi D., Kung’u J., Mugwe J., Merckx R., Vanlauwe B. 2010. A staggered maize-legume intercrop arrangement robustly increases crop yields and economic returns in the highlands of central Kenya. Field Crop Research, Vol. 115, Iss. 2. pp. 132-139. https://doi.org/10.1016/j.fcr.2009.10.013

12. Mzoughi N. 2011. Farmers adoption of integrated crop protection and organic farming: Do moral and social concerns matter? Ecological Economics, Vol. 70, pp. 1536-1545. http://dx.doi.org10.1016/j.ecolecon.2011.03.016

13. Niemiec M. 2014. Efficiency of slow-acting fertilizer in the integrated cultivation of chinese cabbage. Ecological Chemistry and Engineering A, Vol. 21, Iss. 3, pp. 333-346. https://doi.org/10.2428/ecea.2014.21(3)27

14. Niemiec M., Cupiał M., Szeląg-Sikora A., 2015a. Evaluation of the Efficiency of Celeriac Fertilization with the Use of Slowacting Fertilizers. Agriculture and Agricultural Science Procedia, Vol. 7, pp. $177-183$. https://doi.org/10.1016/j.aaspro.2015.12.014

15. Niemiec M., Szeląg-Sikora A., Cupiał M. 2015b Efficiency of celeriac fertilization with phosphorus and potassium under conditions of integrated plant production. Agriculture and Agricultural Science Procedia, Vol. 7, pp. $184-191$. https://doi.org/10.1016/j.aaspro.2015.12.015

16. Nkebiwe P.M., Weinmann M., Bar-Tal A., Müller T. 2016. Fertilizer placement to improve crop nutrient acquisition and yield: A review and meta-analysis. Field Crops Research, Vol. 196, pp. 389-401. https://doi.org/10.1016/j.fcr.2016.07.018

17. Regulation of the Minister of Agriculture of 8 April 2013 amending the Regulation on Integrated Production. Journal of Laws 2013 item 452.

18. Verzeaux J., Hirel B., Dubois F., Leac P.J., Tétu T. 2017. Agricultural practices to improve nitrogen use efficiency through the use of arbuscular mycorrhizae: Basic and agronomic aspects. Plant Science, Vol. 264, pp. 48-56. https://doi.org/10.1016/j.plantsci.2017.08.004

19. Wang Z., Heiniger R.W., Ronald J., Gehl R.J., Heitman A.J., Miguel S., Castillo M.S., Smyth T.J., Carl R., Crozier C.R. 2017. Nitrogen Fertilization Effects on Yield and Nutrient Removal of Biomass and Sweet Sorghum. Agronomy Journal, Vol. 109, Iss. 4, pp. 1-7. https://doi.org/10.2134/agronj2016.12.0710 